\title{
Implementasi Evaluasi Berbasis Hots ( Higher Order Thinking Skill) Terhadap Peningkatan Kemampuan Penalaran Verbal Siswa Dalam Pembelajaran Pai Di Smpn 7 Bekasi
}

\author{
Eva Dwi Kumala Sari \\ STIT Al Marhalah Al Ulya Bekasi \\ Email: kumalasarieva@gmail.com
}

\begin{abstract}
Increasing the ability to think at a high level in schools is an important foundation to help students in reasoning and understanding Islamic religious education in depth. One of the things that can be done by schools to improve higher order thinking skills and reasoning is to provide continuous evaluation of HOTS-based learning, which is the object of this research is to find out: (1) whether there is an influence between the implementation of HOTS-based evaluation of improvement verbal reasoning ability of students in learning PAI.

This research was conducted at SMPN 7 Bekasi. The sample in this study were 70 students using cluster random sampling. Data in this study were analyzed using regression analysis, with a significance level of $\alpha=$ 0.05. The results of this study are: (1) There is an effect between the implementation of the HOTS-based evaluation of improving students' verbal reasoning skills in PAI learning. Keywords: HOTS-based evaluation, verbal reasoning.
\end{abstract}

Keywords: HOTS-based evaluation, verbal reasoning. 


\section{PENDAHULUAN}

Dalam UU Sisdiknas No.20 tahun 2003 disebutkan bahwa pendidikan nasional bertujuan untuk berkembangnya potensi peserta didik agar menjadi manusia yang beriman dan bertaqwa kepada Tuhan Yang Maha Esa, berakhlak mulia, sehat, berilmu, cakap, kreatif, mandiri, dan menjadi warga negara yang demokratis serta bertanggung jawab.

Untuk mengembangkan amanat UU Sisdiknas tersebut, peranan keluarga, sekolah, dan masyarakat sangat besar sebagai tempat strategis untuk mewujudkannya. Peran serta sekolah dalam hal ini sangat signifikan karena peserta didik menggunakan sebagian besar waktunya di sekolah. Menurut Irsyad Djuwaeli, pendidikan dalam jenis sekolah merupakan wadah yang secara ideal menjadi tempat paling memungkinkan bagi pengembangan potensi anak didik secara menyeluruh. ${ }^{1}$

Demikian halnya dengan agama, menurut Mukti Ali, mantan Menteri Agama Republik Indonesia, agama adalah percaya akan adanya Tuhan Yang Maha Esa dan hukum-hukum yang diwahyukan kepada kepercayaan utusan-utusan-Nya untuk kebahagiaan hidup manusia di dunia dan akhirat. ${ }^{2}$ Pendidikan agama merupakan suatu upaya mengembangkan dan mengarahkan siswa menjadi manusia masa depan yang ideal lengkap dalam dimensi religiusnya. ${ }^{3}$

Pendidikan Agama Islam (PAI) adalah usaha sadar untuk menyiapkan peserta didik dalam meyakini, memahami, menghayati, dan mengamalkan agama Islam melalui kegiatan, bimbingan, pengajaran, atau latihan, sehingga menjadi manusia muslim yang beriman dan bertaqwa

${ }^{1}$ M. Irsyad Djuwaeli, Pembaharuan Kembali Pendidikan Islam, (Jakarta: Karsa Utama Mandiri, 1998), p. 8.

${ }^{2}$ A. Muchtar, Tunduk kepada Allah; Fungsi dan Peran Agama dalam Kehidupan Manusia, (Jakarta: Khazanah Baru, 2001), p. 10.

${ }^{3}$ Muslih Usa. (ed), Pendidikan Islam di Indonesia; antara sikap dan Fakta, (Yogyakarta: Tiara Wacana,2001), p. 99. 
kepada Allah swt, serta mengamalkan ajaran agamanya dalam kehidupan sehari-hari baik dalam kehidupan pribadi maupun dalam kehidupan beragama, memperkuat kepribadian dan bersama-sama bertanggung jawab terhadap pembangunan bangsa dan negara. Pendidikan agama pada dasarnya mengarahkan anak didik pada pembentukan sikap dan perilaku yang sesuai dengan ajaran agama. Di samping itu, dalam praktiknya, penyajian materi Pendidikan Agama Islam yang disampaikan dan diterima anak didik sebagai suatu nilai kebenaran Allah mutlak, akan tetapi tidak merupakan jaminan bahwa nilai yang diterimanya itu akan menjadi sikap dan perilakunya. Berdasarkan hasil penelitian yang dilakukan Yusuf, menunjukkan bahwa di antara faktor-faktor yang paling rendah pengaruhnya dalam membentuk sikap dan amal keagamaan anak didik ternyata terletak pada pelajaran Pendidikan Agama Islam di sekolah. ${ }^{4}$

Untuk menilai sejauh mana peserta didik telah memahami dan merasakan nilai-nilai keagamaan, perlu diadakan evaluasi secara berkelanjutan, baik evaluasi formatif maupun evaluasi sumatif. Evaluasi formatif merupakan satu tahapan kegiatan yang dilakukan pada saat program pembelajaran sedang berangsung. Hal ini dilakukan dengan maksud untuk memantau kemajuan belajar siswa dan untuk memberikan umpan balik, baik kepada siswa maupun kepada guru. ${ }^{5}$ Evaluasi ini dilakukan untuk mengetahui sejauh mana para siswa telah memahami materi pelajaran tersebut dan juga untuk mengetahui kelemahan-kelemahan yang terjadi pada proses pembelajaran, seperti ketepatan metode, media, dan sistem evaluasi yang digunakan dalam proses pembelajaran tersebut. Kegiatan ini dilakukan untuk

\footnotetext{
${ }^{4}$ Zaghlul Yusuf, Pengembangan Kurikulum pada Sekolah- Sekolah Islam, (Jakarta: Seminar Pengembangan Pendidikan al- Irsyad, 31 Juli 1988), p. 10.

${ }^{5}$ Suke Silverius, Evaluasi Hasil Belajar dan Umpan Balik, (Jakarta: PT. Grasindo 1991), p. 9.
} 
memperoleh umpan balik yang tepat sehingga proses pembelajaran bisa disempurnakan dan menjadi lebih efektif.

Untuk meningkatkan keterampilan berpikir tingkat tinggi dalam meningkatkan penalaran dalam memahami ilmu- ilmu agama, peneliti mencoba menerapkan evaluasi yang berbasis HOTS ( Higher Order Thingking Skill) dalam pembelajaran PAI. Keterampilan berpikir dapat digolongkan menjadi dua, yaitu lower oder thinking skill (LOTS), dan higher order thinking skill (HOTS). Menurut King, HOTS seseorang akan muncul apabila seseorang menemui permasalahan yang tidak biasa, tak terduga, pertanyaan atau dilema. HOTS menurut Yee Mei Heong, Merupakan aspek penting dalam proses pendidikan. Keterampilan berpikir seorang siswa dapat mempengaruhikemampuan, kecepatan dan efektifitas dalam belajar. Siswa yang terlatih untuk berpikir menunjukkan pengaruh positif terhadap perkembangan pendidikan mereka. Oleh karena itu perlu dikembangkan suatu evaluasi yang dapat digunakan untuk mengukur HOTS siswa dalam pembelajaran PAI di SMP. Menurut Wang dan Wang, terdapat tiga komponen utama dalam HOTS, yaitu keterampilan berpikir kritis, berpikir desain, dan berpikir sistem, sedangkan menurut Miri et. al., HOTS terdiri dari tiga komponen, yaitu berpikir kritis, sistem, dan kreatif. Selanjutnya menurut Rosnawati dan Yee Mei Hong, kemampuan berpikir kritis dan kreatif merupakan dua indikator penting dalam HOTS. Dengan demikian, HOTS terdiri dari dua indikator, sehingga untuk mengetahui HOTS siswa dilakukan melalui pengamatan terhadap keterampilan berpikir kritis dan kreatif.

HOTS merupakan variabel laten yang tidak dapat diukur secara langsung, untuk dapat mengukur variabel laten menurut Naga, dibutuhkan variabel manifes yang sepadan dengan variabel laten yang akan diukur. Pengukuran variabel manifes yang sepadan dengan variabel laten memerlukan instrumen baku. Pada penelitian ini peneliti mencoba membuat 
Implementasi Evaluasi Berbasis Hots ( Higher Order Thinking Skill) Terhadap Peningkatan Kemampuan Penalaran Verbal Siswa... instrumen yang sudah diujicobakan sebelumnya, untuk dijadikan alat sebagai pengukur HOTS.

Selanjutnya adalah tentang penalaran yang akan dihubungkan dengan evaluasi berbasis HOTS, Jujun S. Suriasumantri menyatakan bahwa penalaran merupakan kegiatan berpikir yang memiliki ciri-ciri tertentu, yaitu: (1) adanya suata pola berpikir yang disebut logika, sehingga kegiatan penalaran merupakan suatu proses berpikir logis dan (2) memiliki sifat analitik dari proses berpikir. Selanjutnya, dijelaskan bahwa penalaran dapat dibedakan menjadi penalaran induktif dan deduktif. Penalaran induktif adalah cara berpikir di mana ditarik simpulan umum dari kasus-kasus individual. Sedangkan penalaran deduktif adalah kegiatan berpikir di mana dari pernyataan yang bersifat umum ditarik simpulan yang bersifat khusus. Penarikan simpulan secara deduktif dinamakan silogismus. ${ }^{6}$

Sehubungan dengan silogismus, Carlson dan Buskist menyatakan bahwa silogismus adalah suatu susunan pernyataan logis yang terdiri atas premis mayor, premis minor, dan simpulan. Premis mayor dan premis minor diasumsikan benar, dan kebenaran simpulan itu dinilai dari penalaran deduktif. $^{7}$

Leahhey dan Harris, menyatakan bahwa penalaran adalah suatu proses tentang penarikan simpulan logis berdasarkan fakta atau premispremis. Terdapat dua bentuk penalaran, yaitu penalaran induktif dan penalaran deduktif. Penalaran induktif meliputi penarikan simpulan umum dari seperangkat data, sedangkan penalaran deduktif meliputi penarikan

\footnotetext{
6 Jujun S. Suriasumantri,Filsafat Ilmu, Sebuah Pengantar Populer ( Jakarta: Pustaka Sinar Harapan, 1998), pp. 42- 49.

${ }^{7}$ Neil R. Carlson and William Buskist, The Science of Behavior ( Boston: Allyn and Bacon, 1997),p. 341.
} 
simpulan khusus dari seperangkat pernyataan-pernyataan atau premispremis. $^{8}$

Untuk mengukur kemampuan penalaran verbal dapat digunakan subtes dari tes bakat atau tes intelegensi karena kemampuan penalaran verbal adalah salah satu aspek dari berpikir, sedangkan berpikir merupakan bagian dari intelegensi. Berdasarkan teori "multifaktor" dari Thurstone yang dilaporkan oleh Anastasi bahwa intelegensi terdiri atas kemampuan mental utama (primary mental abilities) yang meliputi: (1) kemampuan verbal (verb comprehension), (2) kelancaran kata-kata (words fluency), (3) kemampuan numerik (number), (4) kemampuan ruang (space), (5) kemampuan memori (associative memory), kecepatan persepsi (perceptual speed), dan (7) induksi atau kemampuan penalaran umum (induction or general reasoning). Sedangkan kemampuan verbal (verbal comprehension) melliputi pemahaman membaca, analogi verbal, mengacaukan kalimat, penalaran verbal, dan menjodohkan peribahasa. ${ }^{9}$ Dengan demikian, jelaslah bahwa penalaran verbal merupakan bagian dari kemampuan verbal. Oleh karena itu, dapat dikatakan bahwa tes untuk mengukur kemampuan penalaran verbal adalah subtes dari kemampuan verbal (vebal comprehension). Menurut Thorndike, tes penalaran verbal (verbal reasoning tests) adalah subtes dari Stanford-Binnet yang terdiri atas subtes berikut: (1) perbendaharaan kata-kata (vocabulary), untuk semua umur, (2) pemahaman (comprehension), untuk semua umur, (3) kemustahilan (absurdities), untuk usia 2-14 tahun, dan (4) hubungan verbal (verbal relation), untuk usia 11 tahun ke atas. ${ }^{10}$

\footnotetext{
8 Thomas Hardy Leahey dan Richard Jackson Hams, Learning and Cognition ( New Jersey: Prentice-Hall, Inc., 1997), p. 229.

9 Anne Anastasi and Susana Urbina, Psychological Testing (London: Prentice Hall, Inc., 1997), pp.312-313.

${ }^{10}$ Robert M, Thorndike, Measurement and Evaluation in Psychology and Education (New Jersey: Prentice-Hall, Inc., 1997), p. 228.
} 
Implementasi Evaluasi Berbasis Hots ( Higher Order Thinking Skill) Terhadap Peningkatan Kemampuan Penalaran Verbal Siswa...

\section{METODE PENELITIAN}

Metodologi yang digunakan dalam penilitian ini adalah metode kuantitatif, analisis data menggunakan analisis regresi. Variabel dalam penelitian ini adalah (1) variabel terikat adalah evaluasi berbasis HOTS, (2) variabel bebas adalah kemampuan penalaran verbal dalam pembelajaran PAI.

Populasi terjangkau penelitian ini adalah seluruh siswa kelas VII SMPN 7 Bekasi. Sampel penelitian ditentukan dengan teknik cluster random sampling. Alasan mengambil sampel kls VII. Jumlah populasi sebanyak 315 siswa, sampel sebanyak 70 siswa diambil dari populasi dengan menggunakan teknik multistage sampling.

Pengumpulan data dilakukan langsung oleh peneliti. Dengan menggunakan teknik pengumpulan kuesioner (angket) dengan cara memberi seperangkat perntanyaan tertulis kepada responden untuk dijawab berupa instrumen yaitu : 1) evaluasi berbasis HOTS dan 2) instrumen penalaran verbal.

\section{HASIL PENELITIAN}

Hipotesis dalam penelitian ini secara inferensia diuji dengan menggunakan Analisis Regresi Berganda. Dalam penelitian ini terdapat satu variabel bebas dan satu variabel kriteria. Variabel bebas adalah evaluasi berbasis HOTS sedangkan variabel kriteria adalah kemampuan penalaran verbal. Setelah dilakukan perhitungan dengan menggunakan program SPSS version 20, maka analisis data disajikan pada tabel- tabel dibawah ini. 
One-Sample Kolmogorov-Smirnov Test

\begin{tabular}{|ll|r|r|}
\hline & & HOTS & $\begin{array}{r}\text { Penalaran_verb } \\
\text { al }\end{array}$ \\
\hline N & & 70 & 70 \\
Normal Parameters & & \\
& Mean & 115,17 & 69,47 \\
& Std. Deviation & 14,369 & 6,650 \\
& Absolute &, 059 &, 069 \\
Most Extreme Differences & Positive &, 058 &, 064 \\
& Negative &,- 059 &,- 069 \\
Kolmogorov-Smirnov Z & &, 495 &, 573 \\
Asymp. Sig. (2-tailed) & &, 967 &, 897 \\
\hline
\end{tabular}

a. Test distribution is Normal.

b. Calculated from data.

Dari tabel diatas diketahui bahwa nilai Asymp.sig.(2-tailed) dari uji normalitas kolmogorov-Smirnov adalah 0,495 pada HOTS dan 0,897 pada penalaran verbal lebih besar dari alfa 0,05 maka $\mathrm{H}_{0}$ diterima, berarti sampel penelitian ini adalah berdistibusi normal.

Hasil penelitian pada uji signifikansi yang dijelaskan pada tabel ANOVA $^{\mathrm{a} .}$.

\section{ANOVA $^{\mathrm{a}}$}

\begin{tabular}{|rl|r|r|r|r|r|}
\hline Model & & Sum of Squares & df & Mean Square & F & Sig. \\
\hline \multirow{2}{*}{1} & Regression & 2918,805 & 1 & 2918,805 & 1496,393 &, $000^{\circ}$ \\
& Residual & 132,638 & 68 & 1,951 & & \\
& Total & 3051,443 & 69 & & & \\
\hline
\end{tabular}

a. Dependent Variable: Penalaran_verbal

b. Predictors: (Constant), HOTS

Dari uji signifikansi tersebut didapat sig atau P- Value 0,000 dengan 
Implementasi Evaluasi Berbasis Hots ( Higher Order Thinking Skill) Terhadap Peningkatan Kemampuan Penalaran Verbal Siswa...

demikian $\mathrm{H}_{0}$ ditolak, berarti terdapat pengaruh yang signifikan antara implementasi evaluasi berbasis HOTS terhadap kemampuan penalaran verbal.

Coefficients $^{\mathrm{a}}$

\begin{tabular}{|c|c|c|c|c|c|}
\hline \multirow[t]{2}{*}{ Model } & \multicolumn{2}{|c|}{ Unstandardized Coefficients } & \multirow{2}{*}{$\begin{array}{c}\text { Standardized } \\
\text { Coefficients }\end{array}$} & \multirow[t]{2}{*}{$\mathrm{t}$} & \multirow[t]{2}{*}{ Sig. } \\
\hline & $B$ & Std. Error & & & \\
\hline (Constant) & 17,340 & 1,358 & & 12,769 & 000 \\
\hline HOTS & ,453 & 012 & ,978 & 38,683 & 000 \\
\hline
\end{tabular}

a. Dependent Variable: Penalaran_verbal

Sedangakan dari tabel Coefficients ${ }^{\mathbf{a}}$, didapat pula sig/ P- Value 0,000 dengan demikian H0 ditolak, berarti semakin sering diterapkan evaluasi berbasis HOTS maka semakin tinggi pula kemampuan penalaran verbal siswa pada pembelajaran PAI.

Model Summary

\begin{tabular}{|l|r|r|r|r|}
\hline Model & \multicolumn{1}{|c|}{$\mathrm{R}$} & $\mathrm{R}$ Square & \multicolumn{1}{c|}{$\begin{array}{c}\text { Adjusted } \mathrm{R} \\
\text { Square }\end{array}$} & $\begin{array}{c}\text { Std. Error of the } \\
\text { Estimate }\end{array}$ \\
\hline 1 &, $978^{\mathrm{a}}$ &, 957 &, 956 & 1,397 \\
\hline
\end{tabular}

a. Predictors: (Constant), HOTS

Dilihat dari tabel model sumary untuk mengetahui koefisien korelasi atau keeratan hubungan evaluasi berbasis HOTS mempengaruhi kemampuan penalaran verbal sebesar $95 \%$. Hal ini membuktikan bahwa memang sangat penting diterapkannya evaluasi berbasis HOTS disekolah akan sangat meningkatkan kemampuan penalaran verbal siswa dalam pembelajaran PAI disekolah, dan akan membantu siswa dalam memahami ajaran PAI dengan kemampuan berpikir tingkat tinggi dan mampu menerapkan dalam kehidupan sehari-hari. 
Eva Dwi Kumala Sari

\section{PEMBAHASAN}

Hasil analisa data dengan menggunakan Analisis Regresi pada taraf signifikansi $\alpha=0,05$, tersebut di atas, memberikan nilai $F_{\text {observasi }}\left(F_{o}\right)=$ 1496,393dengan sig/ $p=$ value 0.000 . Hal ini berarti bahwa $H_{o}$ ditolak. Sebagai konsekuensinya maka $\mathrm{H}_{1}$ diterima. Dengan uji-Tukey, didapatkan sig/ pvalue sebesar 0,000 berarti lebih besar dari $\alpha=0,05$, berarti $H_{0}$ ditolak. Dengan demikian dapat disimpulkan bahwa terdapat pengaruh yang signifikan antara evaluasi berbasis HOTS terhadap kemampuan penalaran verbal, dan dengan dilaksanakannya evaluasi berbasis HOTS di sekolah maka akan mempengaruhi kemampuan penalaran verbal siswa sebesar 38,7\%.

\section{KESIMPULAN}

Sesuai dengan temuan dan pembahasan tersebut di atas dapat disimpulkan sebagai berikut: apabila penerapan evaluasi berbasis HOTS diterapkan di sekolah akan sangat meningkatkan kemapuan penalaran verbal siswa. Dengan demikian maka dapat ditegaskan bahwa untuk mencapai kemapuan penalaran verbal siswa yang optimal perlu dilakukan dengan menerapkan evaluasi berbasis HOTS di sekolah- sekolah.

\section{DAFTAR PUSTAKA}

A. Muchtar, Tunduk kepada Allah; Fungsi dan Peran Agama dalam Kehidupan Manusia, Jakarta: Khazanah Baru, 2001.

Abu Syuhbah, Muhammad. Etika Membaca dan Mempelajari al- Quran, terjemahan Taufikqurrahman. Bandung: Pustaka Setia. 2003.

Arikunto, Suharsimi. Dasar-dasar Evaluasi Pendidikan. Jakarta: Bumi Aksara. 2012.

Arifin, Syamsul Bambang. Psikologi Agama. Bandung: Raja Grafindo Persada, 2005. 
Implementasi Evaluasi Berbasis Hots ( Higher Order Thinking Skill) Terhadap Peningkatan Kemampuan Penalaran Verbal Siswa...

Djaali dan Pudji Mulyono. Pengukuran Dalam Bidang Pendidikan, Jakarta:

Program Pascasarjana Universitas Negeri Jakarta, 2004.

Gagne, Robert M. The Conditions of Learning, New York: Holt Rinehart and Winston, 1983.

Gronlund Norman E., How to Make Achievement Test and Assessments, Fifth

Edition, USA: University of Illinois Allyn and Bacon, Boston London Toronto Sidney Tokyo Singapore, 1993.

Hakim, Atang Abd. Metodologi studi Islam. Bandung: Remaja Rosdakarya, 2000.

Mangunwijaya, Y. B. Menumbuhkan Religius Anak- anak. Jakarta: Gramedia, 1991.

M. Irsyad Djuwaeli, Pembaharuan Kembali Pendidikan Islam, Jakarta: Karsa Utama Mandiri, 1998.

Muhibbin Syah. Psikologi Pendidikan dengan Pendekatan Baru, Bandung: Remaja Rosdakarya, 2007.

Mulyono Abdulrahman dan Totok Bintoro. Memahami dan Menangani siswa dengan problema dalam Belajar. Ditjen Pendidikan Dasar dan Menengah, Departemen Pendidikan Nasional, 2000.

Muslih Usa. (ed), Pendidikan Islam di Indonesia; antara sikap dan Fakta, Yogyakarta: Tiara Wacana,2001.

Naga S Dali.., Pengantar Teori Sekor pada Pengukuran Bidang Pendidikan. Jakarta: Guna Dharma, 1992.

Naga S Dali., Probabilitas dan Sekor pada Hipotesis Statistika. Jakarta: Universitas Tarumanegara, 2008.

Rahmat Jalaluddin, Psikologi Komunikasi, Bandung: Remaja Rosdakarya, 2001. 
Eva Dwi Kumala Sari

Semiawan Conny, Kreativitas Keberbakatan Jakarta: Indeks, 2009 , Perspektif Pendidikan Anak Berbakat, Jakarta: Grasindo, 1997.

Sudjana, Metode Statistik, Bandung: Tarsito, 2005.

Sudjana Nana, Penilaian Hasil Proses Belajar Mengajar, Bandung: Remaja Rosdakarya, 1999.

Sugiyono, Metode Penelitian Pendidikan. Bandung: Alfabeta, 2006.

Suke Silverius, Evaluasi Hasil Belajar dan Umpan Balik, Jakarta: PT. Grasindo 1991.

Uno B. Hamzah .,. Orientasi Baru dalam Psikologi Pembelajaran. Jakarta: Bumi Aksara, 2006.

Wiersma, William and Jurs, Stephan G. Education Measurement and Testing Second Edition.( USA: The University of Teledo Allyn Bacon, 1990. Zaghlul Yusuf, Pengembangan Kurikulum pada Sekolah- Sekolah Islam, Jakarta: Seminar Pengembangan Pendidikan al- Irsyad, 31 Juli 1988. 